Elżbieta Tomkiewicz ${ }^{1}$

\title{
Legitymizacja organizacji rolników w UE i ich wpływ na regulacje unijnego prawa rolnego
}

1. W konferencji naukowej poświęconej pamięci Prof. Andrzeja Stelmachowskiego nie może zabraknąć problematyki dotyczącej wolności zrzeszania się rolników, którą Profesor podejmował i to zarówno w wymiarze czysto teoretycznym, jak też w praktyce politycznej trudnych lat 80-tych. Od samego początku Profesor był ściśle z związany z ruchem „Solidarności Rolników Indywidualnych”, a w obradach Okrągłego stołu zajmował się sprawami pluralizmu związkowego w ramach zespołu do spraw wsi i rolnictwa.

Zagwarantowana przez przepisy prawodawstw krajowych, jak też prawo międzynarodowe wolność zrzeszania ma nadal szczególnie doniosłe znaczenie dla rolników, którzy z racji tego, że działają w rozproszeniu, mają bardzo słabą pozycję w stosunku do organów władzy publicznej. Problematyka ta zyskała niepomiernie na znaczeniu od 2004 r. w kontekście reprezentacji interesów polskich rolników na forum Unii Europejskiej.

2. Wraz z nasilającymi się procesami globalizacji i integracji europejskiej rośnie rola organizacji społeczeństwa obywatelskiego, które mają przyczyniać się do pogłębiania demokratyzacji procesu decyzyjnego w UE, odgrywając rolę swoistego pośrednika między obywatelami europejskimi i organami unijnymi. Zakorzeniony w europejskiej tradycji model dialogu społecznego wymaga współdziałania organów unijnych i partnerów społecznych, do których zalicza się przede wszystkim związki zawodowe (syndykalne), organizacje pracodawców, organizacje pozarządowe itd ${ }^{2}$. Wobec niedostatecznej reprezentatywności i legitymizacji instytucji unijnych, niemających, poza Parlamentem Europejskim, bezpośredniego mandatu pochodzącego z wyborów, włączenie partnerów społecznych w proces podejmowania decyzji głównie ma na celu wzmocnienie demokratycznej legitymizacji organów unijnych. Podkreślić jednak należy, że mimo wciąż nowych i coraz bardziej inten-

J. Barcz, Pięć lat członkostwa Polski w Unii Europejskiej. Zagadnienia polityczno-ustrojowe, Warszawa 2009, s 184 i nast. 
sywnych form współpracy między partnerami społecznymi a organami unijnymi ${ }^{3}$, jak dotąd nie udało się przezwyciężyć deficytu demokracji w UE.

W sektorze rolnym współpraca organizacji zawodowych rolników z organami wspólnotowymi w procesie podejmowania decyzji była szczególnie intensywna od samego początku kształtowania się Wspólnot Europejskich, znacznie wyprzedzając pod tym względem działalność przedstawicieli innych sektorów gospodarki. Już $\mathrm{w}$ drugiej połowie lat 50-tych na szczeblu WE powstało szereg rolniczych organizacji zawodowych, które zgodnie z zasadą pluralizmu związkowego miały reprezentować na forum europejskim heterogeniczne interesy różnych kategorii rolników z poszczególnych państw członkowskich (np. interesy młodych rolników, spółdzielców czy pracowników rolnictwa).

Historycznie pierwszą i do dziś najważniejszą taką organizacją jest powołany już w 1958 r. Komitet Rolniczych Organizacji Zawodowych przy UE (Comité des Organisations Professionnelles Agricoles de l'Union Europénne, w skrócie COPA ${ }^{4}$ ), który został utworzony na podstawie porozumienia zawartego między 6 centralami rolniczych organizacji zawodowych sześciu państw założycielskich EWG. W tym samym roku do reprezentowania i ochrony interesów zawodowych pracowników rolnictwa powołano Europejską Federację Związków Zawodowych Pracowników Rolnictwa (Fédération Europénne des Syndicats des Travailleurs Agricoles, w skrócie $\mathrm{EFA}^{5}$ ). Kolejną organizacją rolników powołaną w 1958 r. była Europejska Rada Młodych Rolników (Conseil Européene des Jeunes Agriculteurs, w skrócie CEJA'), która zrzesza federacje Związków Zawodowych Młodych Rolników z państw członkowskich. Z kolei reprezentacja rolników spółdzielców z państw członkowskich na szczeblu ponadkrajowym powołana została w 1959 r. w postaci Głównego Komitetu Spółdzielczości Rolniczej (Comité Général de la Coopération Agricoles de l’Union Europénne, w skrócie COGECA ${ }^{7}$ ). Podobieństwo celów działania tej organizacji i COPA przesądziło o utworzeniu w 1962 r. wspólnego w sensie technicznym sekretariatu COPA-COGECA, w którym COPA zajmuje dominującą pozycję.

Na skutek transformacji procesu decyzyjnego ze szczebla krajowego na szczebel unijny ponadnarodowe organizacje rolników, podobnie zresztą jak i inne organizacje, usytuowały swoją działalność w Brukseli w pobliżu organów unijnych ${ }^{8}$, w celu skuteczniejszego formułowania wobec nich swoich postulatów i stanowisk. Organizacje te mają szczególny status prawny, co wyraża się w tym, że pod wzglę-

K. Wódz, Dialog obywatelski w Unii Europejskiej, (w:) Tożsamość społeczno-kulturowa miasta postindustrialnego w Europie Środkowej, pod red. B. Klocha i A. Stwarza, Warszawa-Rybnik 2005.

4 B. Kozłowska, Pozycja prawna organizacji syndykalnych w europejskiej integracji rolnictwa, Warszawa 1998, s. 72 i nast.

B. Kozłowska, Rolnicze organizacje zawodowe na obszarze Unii Europejskiej, Warszawa 1995, s. 21 i nast. Ibidem, s. 19 i nast.

Ibidem, s. 18 i nast.

M. Matyja, Wpływ Zrzeszenia Konfederacji Przemysłowców i Pracodawców Europy (UNICE) na proces decyzyjny w Unii Europejskiej, Warszawa 2000, s. 11. 
dem organizacyjno-prawnym są niezależne od organów unijnych, choć zarazem pod względem funkcjonalnym są z nimi ściśle związane, współpracując z Komisją UE, Radą UE, Parlamentem Europejskim oraz Komitetem Społeczno-Ekonomicznym i Komitetem Regionów o charakterze opiniodawczo-doradczym.

3. Prawo uczestniczenia w mechanizmach dialogu społecznego na szczeblu UE mają te organizacje ponadnarodowe, które spełniają ściśle określone kryteria. Zostały one sformułowane przez prawodawcę unijnego na tyle ogólnie, by umożliwić możliwie dużej liczbie partnerów społecznych reprezentowanie swoich interesów zawodowych na forum unijnym. Początkowo kryteria te zostały określone w komunikacie Komisji z 14 grudnia 1993 r. dotyczącym wprowadzenia w życie postanowień Protokołu w sprawie polityki społecznej ${ }^{9}$, a następnie w identycznym niemal brzemieniu powtórzone w decyzji Komisji z dnia 20 maja 1998 r. w sprawie ustanowienia Komitetów Dialogu Sektorowego promujących dialog między partnerami społecznymi na szczeblu europejskim ${ }^{10}$. Jak wynika z treści art. 1 przytoczonej decyzji, organizacja zorganizowana na szczeblu europejskim powinna odnosić się do określonej dziedziny życia społecznego lub gospodarczego i składać z organizacji krajowych o uznanej pozycji $w$ danym kraju. Jednocześnie organizacja działająca na szczeblu unijnym powinna mieć odpowiednią strukturę organizacyjno-prawną, gwarantującą jej efektywny udział w procesie podejmowania decyzji w UE.

Na podstawie tych kryteriów Komisja sporządziła listę uznanych formalnie partnerów społecznych ${ }^{11}$, zaliczając do nich także działające na szczeblu unijnym organizacje rolników. W odróżnieniu od organizacji horyzontalnych, które reprezentują interesy ponadsektorowe (np. Unia Konfederacji Przemysłowców i Pracodawców Europy - UNICE) organizacje rolnicze są kwalifikowane jako organizacje o charakterze sektorowym (branżowym). Zgodnie bowiem $\mathrm{z}$ wymogiem określonym w art. 1 lit. a) przytoczonej decyzji Komisji reprezentują one interesy sektora rolnego, ujmowanego obecnie w bardzo szerokim znaczeniu. Do czasu zasadniczych reform wspólnej polityki rolnej Mc Sharry'ego z 1992 r. ponadnarodowe organizacje rolnicze koncentrowały się głównie na ochronie produkcyjności rolnictwa wspólnotowego, w tym zwłaszcza na zapewnieniu rolnikom odpowiednio wysokiego poziomu wspólnych cen rolnych ${ }^{12}$. Tymczasem obecna koncepcja europejskiego modelu rolnictwa, oparta na założeniu jego wielofunkcyjnej natury, zakłada, że sektor ten pełni nie tylko tradycyjne funkcje w zakresie produkcji żywności, ale także funkcje związane $\mathrm{z}$ ochroną środowiska naturalnego oraz funkcje społeczne związane $\mathrm{z}$ polity-

9 COM $1993 / 600$ final/.

10 Decyzja Komisji notyfikowana jest jako dokument $\mathrm{nr}$ C/1998/2334.

11 E. Gromnicka, Komentarz do art. 137 Traktatu ustanawiającego Wspólnotę Europejską, (w:) „Traktat ustanawiający Wspólnotę Europejską". Komentarz pod red. A. Wróbla, t. 2, Warszawa 2009, s. 1030.

12 E. Tomkiewicz, Limitowanie produkcji w ustawodawstwie rolnym Wspólnoty Europejskiej, Warszawa 2000, s. 22 i nast. 
ką rozwoju obszarów wiejskich ${ }^{13}$. Oznacza to, że zainteresowanie organizacji rolniczych wykracza zdecydowanie poza wspólną politykę rolną, obejmując także inne unijne polityki sektorowe, $\mathrm{w}$ tym m.in. politykę ochrony środowiska, politykę regionalną, politykę ochrony konsumenta, zwłaszcza w kontekście bezpieczeństwa żywności i odpowiedniej jej jakości ${ }^{14}$. Nakłada to na organizacje rolnicze obowiązek ścisłej współpracy z innymi partnerami społecznymi, w tym zwłaszcza europejskimi organizacjami ekologicznymi i organizacjami konsumentów, obrońców zwierząt, które w wielu kwestiach mają zasadniczo odmienne stanowiska, w tym m.in. w odniesieniu do produkcji żywności modyfikowanej genetycznie, zakazu stosowania hormonów w hodowli bydła.

Kolejny warunek udziału organizacji rolniczej w dialogu społecznym na forum UE, o którym mowa w art. 1 lit. b) decyzji Komisji, jest taki, by jej członkami były organizacje o charakterze demokratycznym, mające silną i uznaną pozycję w danym państwie, które są utworzone i funkcjonują zgodnie z przepisami prawa krajowego. Wraz z kolejnymi rozszerzeniami UE i zarazem rosnącą rolą dialogu społecznego systematycznie wzrasta liczba organizacji krajowych zrzeszonych w ramach struktur ponadnarodowych, Odwołując się do przykładu najbardziej wpływowej organizacji rolniczej działającej w Brukseli, jaką jest COPA, należy zauważyć, że o ile $a b$ initio zrzeszała ona zaledwie 13 organizacji krajowych, to obecnie należy do niej 60 organizacji rolniczych z państw członkowskich UE i 36 organizacji partnerskich z innych państw europejskich, w tym m.in. Norwegii, Szwajcarii, Turcji. Z kolei do COGECA należy 76 krajowych organizacji rolniczych i tyleż samo organizacji partnerskich co do COPA. Tak duża liczba zrzeszonych organizacji w ramach struktury ponadnarodowej wskazuje na to, że niektóre państwa reprezentowane są w UE przez więcej niż przez jedną organizację krajową (m.in. Estonia - 2, Litwa - 5, Włochy -3 organizacje). Wynika to z uwarunkowań historycznych danego kraju członkowskiego, dużego znaczenia sektora rolnego w jego gospodarce, a nade wszystko $\mathrm{z}$ braku porozumienia między organizacjami krajowymi ${ }^{15}$. Interesy polskiego sektora rolnego są również reprezentowane w COPA przez kilka organizacji krajowych, tj. Krajowy Związek Rolników, Kółek i Organizacji Rolniczych, Krajową Radę Izb Rolniczych, NSZZ „Solidarność”, Związek Zawodowy Rolnictwa Samoobrona oraz Federację Branżowych Związków Producentów Rolnych ${ }^{16}$. Z kolei w Niemczech, o liczącej się przecież pozycji sektora rolnego, na szczeblu unijnym reprezentowana jest tylko jedna organizacja rolnicza, podobnie jak ma to miejsce w odniesieniu do Austrii, Danii i Irlandii.

E. Tomkiewicz, Polityka rozwoju obszarów wiejskich w kontekście europejskiego modelu rolnictwa, (w:) Prawo w XXI wieku, pod red. W. Czaplińskiego, Warszawa 2006, s. 964 i nast.

M. Gajda, K. Tarnowska: Lobbing rolny a budżet UE, Kraków 2002, s. 52-53.

Ibidem, s. 53.

Reprezentuje ona 23 wiodące związki branżowe. Zob. M. Janicki: Rolnicze zrzeszenia branżowe jako forma organizacyjno-prawna grupy producentów rolnych, „Przegląd Prawa Rolnego” 2010, nr 1, s. 126. 
Działająca na szczeblu unijnym organizacja rolnicza zrzesza organizacje krajowe będące osobami prawnymi, co oznacza, że została ona zorganizowana według zasady federacyjnej. Przepisy ustawodawstw krajowych przewidują różne formy prawne działania rolniczych organizacji zawodowych (m.in. związki zawodowe, zrzeszenia branżowe, spółdzielnie, społeczno-zawodowe organizacje rolników, izby rolnicze, stowarzyszenia itd) ${ }^{17}$. W większości systemów prawnych państw członkowskich podstawą prawną funkcjonowania rolniczych organizacji zawodowych jest specjalne ustawodawstwo związkowe (np. we Francji, Hiszpanii, Wielkiej Brytanii, Polsce) lub też przepisy prawne o charakterze ogólnym (np. kodeks cywilny w Niemczech i we Włoszech, a w Danii - przepisy rangi konstytucyjnej) ${ }^{18}$. Natomiast kwestie szczegółowe w tym zakresie regulują krajowe statuty poszczególnych organizacji zawodowych rolników. W literaturze przedmiotu ponadnarodowe rolnicze zawodowe zrzeszające krajowe organizacje kwalifikowane są jako międzynarodowe organizacje pozarządowe ${ }^{19}$, gdyż ,wypełniają one znamiona organizacji międzynarodowych, których działalność oparta jest na wewnętrznych porozumieniach, niebędących częścią prawa międzynarodowego publicznego" ${ }^{20}$. Jest przy tym oczywiste, że organizacje krajowe reprezentujące interesy rolników na szczeblu unijnym akceptują wspólną politykę rolną i zgodnie z obowiązującymi przepisami opłacają składki członkowskie na rzecz organizacji ponadnarodowej. Jak więc z tego wynika intencją prawodawcy unijnego było zapewnienie odpowiedniej reprezentatywności krajowych organizacji rolniczych w ramach struktur ponadnarodowych. Wydaje się jednak, że trudno jest mówić o pełnej reprezentatywności krajowych organizacji rolniczych na forum UE, skoro reprezentatywność wiąże się z mandatem elekcyjnym i kontrolą ze strony wyborców, a ich przedstawiciele są delegowani do struktur ponadnarodowych przez krajowe instancje organizacyjne, a więc $\mathrm{z}$ woli aparatu związkowego, a nie mandatu danego przez rolników ${ }^{21}$.

Zgodnie z kolejnym warunkiem określonym w art. 1 lit. c) decyzji Komisji z 20 maja 1998 r. ponadnarodowe organizacje rolnicze mają odpowiednio zorganizowane struktury organizacyjno-prawne ${ }^{22}$, które zapewniają im możliwość reprezentowania i obrony interesów rolników na forum unijnym. Struktury te pod wieloma względami są do siebie bardzo podobne ze względu na zbieżne cele i metody działania w procesie stanowienia unijnego prawa rolnego. I tak dla przykładu najważniejszym organem decyzyjnym w strukturze organizacyjnej zarówno COPA, jak i COGECA, jest Prezydium, w skład którego wchodzą liderzy krajowych organiza-

A. Stelmachowski, Społeczno-gospodarcze organizacje rolników, (w:) Polskie prawo rolne na tle ustawodawstwa Unii Europejskiej, pod red. P. Czechowskiego, S. Prutisa, M. Korzyckiej-Iwanow, A. Stelmachowskiego, Warszawa 1999, s.144 i nast.

18 Wskazuje na to B. Kozłowska, Pozycja prawna organizacji.., op. cit., s. 81-82.

19 Z. Doliwa-Klepacki, Encyklopedia organizacji międzynarodowych, Warszawa 1996, s. 15 i nast.

20 B. Kozłowska, Pozycja prawna organizacji..., op. cit., s. 79.

21 Ibidem, s. 237.

22 E. Gromnicka, Komentarz do art. 138 Traktatu..., op. cit., s. 1031. 
cji rolniczych. Prezydium zbiera się raz w miesiącu w celu wypracowania wspólnego stanowiska w imieniu obu organizacji. W jego obradach biorą także udział przedstawiciele innych organizacji rolniczych (m.in. CEJA). Zebrania prezydium COPA są przygotowywane przez dwa Komitety Koordynacji Politycznej: jeden z ramienia COPA, drugi - COGECA. Posiedzenia tych komitetów zwoływane są z dużą częstotliwością - co tydzień. Natomiast głównym organem wykonawczym COPA-COGECA jest Prezydencja, w skład której z kolei wchodzą Przewodniczący i 6 wiceprzewodniczących wybierani spośród członków Komitetu. Posiedzenia Prezydencji odbywają się raz w miesiącu. Pod względem merytorycznym organy te wspierane są przez grupy robocze (50 grup z obu organizacji), które przygotowują propozycje szczegółowych rozwiązań prawnych związanych z regulowaniem branżowych rynków rolnych, jak też rozwiązań o charakterze ogólnym dotyczących m.in. ochrony środowiska naturalnego, rozwoju obszarów wiejskich.

Jeśli przy tym uwzględnić, że sekretariat COPA-COGECA zatrudnia na stałe około 50 osób, to nasuwa się wniosek, że organizacje te mają bardzo rozbudowane i w dodatku zbiurokratyzowane struktury organizacyjne, co w wielu przypadkach utrudnia im dostosowanie się do dynamicznie zmieniających się i coraz bardziej skomplikowanych warunków, w jakich funkcjonuje sektor rolny. W ocenie krajowych organizacji ponadnarodowe struktury reprezentujące rolników nadmiernie utożsamiają się z organami unijnymi, nie zachowując wobec nich niezbędnego dystansu $^{23}$. Takie postrzeganie tych organizacji wynikać może $\mathrm{z}$ faktu, że krajowe organizacje rolnicze działają $w$ interesie własnego rolnictwa, zaś na forum unijnym problemy sektora rolnego rozwiązywane są wspólnie z innymi organizacjami krajowymi, co wymaga stworzenia koalicji wokół wspólnych interesów. W procesie decyzyjnym w UE bowiem wykształciły się mechanizmy wspólnego, ponadnarodowego podejmowania decyzji ${ }^{24}$, które dominują nad artykulacją interesów krajowych.

Ponadnarodowe organizacje rolnicze charakteryzują się wysokim profesjonalizmem, gdyż dysponują znaczącymi środkami finansowymi, pochodzącymi zarówno ze środków publicznych ${ }^{25}$, jak i w niemałym stopniu ze składek członkowskich, co pozwala im na zatrudnienie wysoko kwalifikowanej kadry administracyjnej, dysponującej gruntowną znajomością skomplikowanej materii prawa rolnego oraz, co nie mniej ważne, dobrą znajomością procedur unijnych. W szerokim zakresie korzystają także z wiedzy ekspertów zewnętrznych.

Tak właśnie B. Kozłowska, Pozycja prawna..., op. cit., s. 132.

Zwraca na to uwagę M. Matyja, Wpływ Zrzeszenia Konfederacji, op. cit., s. 44.

I tak dla przykładu, w latach 2008-2013 koszty związane z uczestnictwem 4 polskich organizacji rolniczych w COPA-COGECA są dofinansowane $z$ budżetu państwa $w$ formie dotacji celowej oraz przez Krajową Radę Izb Rolniczych. Zob. ustawę z 12 czerwca 2008 r. o zmianie ustawy o społeczno-zawodowych organizacjach rolników, ustawy o związkach zawodowych rolników indywidualnych oraz ustawy o izbach rolniczych, Dz.U. Nr 139, poz. 876. 
Jednak podkreślić należy, że mimo rozbudowanych struktur organizacyjnych wypracowanie wspólnego stanowiska w ramach ponadnarodowej organizacji rolniczej jest bardzo trudne i często wymaga dłuższego czasu ze względu na przeciwstawne interesy wchodzących w jej skład organizacji krajowych. Jeśli więc ponadnarodowa organizacja rolników prezentuje jednomyślne stanowisko wobec organów unijnych, osiągnięte na zasadzie trudnego kompromisu, to wcale nie musi oznaczać, że jest to stanowisko podzielane przez wszystkie organizacje krajowe. Jeśli natomiast regulowana materia stanowi przedmiot zainteresowania niektórych tylko państw członkowskich (np. rynek wina), to wówczas w uzgadnianiu wspólnego stanowiska wobec organów unijnych nie muszą uczestniczyć wszystkie krajowe organizacje rolników.

4. Ponadnarodowe organizacje zawodowe rolników funkcjonujące w obrębie UE mają znaczący wpływ na kształt wspólnej polityki rolnej i regulującego ją unijnego prawodawstwa rolnego. W toku wieloletniej już praktyki wykształciły się stałe formy udziału rolniczych organizacji w kształtowaniu wspólnej polityki rolnej.

Podstawowe znaczenie ma udział tych organizacji w procesie stanowienia prawa wyrażający się inicjowaniu własnych rozwiązań z zakresu polityki rolnej i przedkładaniu ich organom unijnym oraz obligatoryjnym opiniowaniu projektów aktów prawnych dotyczących zagadnień prawnorolnych. Przyznane im uprawnienia w zakresie konsultowania aktów prawa unijnego są traktowane jako forma partycypacji społeczeństwa obywatelskiego $\mathrm{w}$ procesie tworzenia prawa.

Z uwagi na to, że prawo inicjatywy prawodawczej przysługuje Komisji, która przygotowuje projekty aktów prawnych, najważniejszym partnerem organizacji rolniczych jest Komisja. Przygotowane przez nią projekty aktów prawnych są konsultowane z organizacjami rolniczymi. Problemy polityki rolnej są także przedmiotem regularnych comiesięcznych spotkań Komisji i Prezydium COPA-COGECA. W kwestiach bardziej szczegółowe eksperci COPA kontaktują się z przedstawicielami Komisji. Ponadto prezydium COPA organizuje regularne spotkania z komisarzem ds. rolnictwa.

W stosunku do Rady UE ponadnarodowe organizacje rolnicze stosują inne formy oddziaływania, które polegają głównie na utrzymywaniu stałych kontaktów z ministrami ds. rolnictwa za pośrednictwem krajowych organizacji rolniczych. Podobne działania podejmuje COPA wobec deputowanych Parlamentu Europejskiego. Skuteczną formą działania przedstawicieli rolników w Brukseli są kontakty o charakterze nieformalnym, mające na celu wywarcie wpływu na unijne ośrodki decyzyjne. Niezależnie od tego organizowane są dorażne spotkania z przedstawicielami innych organów w kwestiach dotyczących sektora rolnego UE. 
Działające na szczeblu unijnym zawodowe organizacje rolnicze mają także swoich przedstawicieli w organach doradczych UE, do których należy Komitet Ekonomiczno-Społeczny (art. 301-304 TFUE) i Komitet Regionów (art. 305-307 TFUE). Z komitetami tymi konsultowane są wszystkie sprawy z zakresu wspólnej polityki rolnej i polityki wobec wsi. Komitety te jako instytucje doradcze Parlamentu Europejskiego, Rady, Komisji mają zapewnić udział społeczeństwa obywatelskiego w procesie podejmowania decyzji i tworzenia unijnego prawa rolnego.

Ważną funkcją organizacji rolniczych na szczeblu unijnym jest wymiana informacji ${ }^{26}$, stanowiąca dla grup interesu decydujący czynnik ich skuteczności. Przedstawiciele tych organizacji uczestniczą $w$ organizowanych przez organy unijne konferencjach, spotkaniach i zebraniach, które dotyczą projektowanych rozwiązań prawnych z zakresu wspólnej polityki rolnej.

Podobnie jak krajowe organizacje rolnicze, tak również organizacje ponadnarodowe pełnią ważne funkcje edukacyjne, mające na celu podnoszenie kwalifikacji zawodowych rolników i dostarczenie im wiedzy fachowej w tym zakresie, kształtowanie świadomości ekologicznej, upowszechnianie zasad etyki.

Najbardziej radykalną formą działania rolniczych organizacji zawodowych są manifestacje uliczne, które odbywają się najczęściej w czasie obrad Rady i Komisji UE dotyczących kluczowych spraw dla rolnictwa ${ }^{27}$. Należy podkreślić, że wbrew opiniom o spontaniczności takich manifestacji są one z reguły bardzo starannie przygotowane pod względem organizacyjnym, lącznie z zagwarantowaniem bezpieczeństwa ich uczestnikom. Takim przykładem jest wielka manifestacja zorganizowana 22 lutego 1999 r. na kilka dni przed planowanym szczytem Rady Europejskiej dotyczącym zasadniczych reform wspólnej polityki rolnej. W manifestacji uczestniczyło około 40 tysięcy rolników.

Od samego początku utworzenia EWG, kiedy wspólna polityka rolna była główną siłą napędową integracji europejskiej, ponadnarodowe rolnicze organizacje zawodowe miały ogromny wpływ na kształtowanie wspólnej polityki rolnej i unijnego prawodawstwa rolnego. Przez długie lata były one uznawane za jedne z najbardziej wpływowych grup nacisku i ważny element pluralistycznej demokracji na forum UE, o czym świadczyć może fakt przeznaczania około połowy budżetu wspólnotowego na finansowanie tej polityki. W latach 70-tych i 80-tych ubiegłego wieku,działalność lobby rolniczego koncentrowała się na polityce rynkowo-cenowej, skutecznie wywierając wpływ na kształt rozwiązań prawnych dotyczących branżowych rynków rolnych, w tym głównie instrumentów cenowych. Jednakże po-

Na temat funkcji europejskich grup interesów zob. szerzej L. Graniszewski, C. Piątkowski:, Grupy interesu w Unii Europejskiej, Warszawa 2004, s. 88.

27 B. Kozłowska, Problem reprezentowania rolników we Wspólnocie Europejskiej, „Studia luridica Agraria” 2000, t. 1 , s. 132. 
cząwszy od lat 90-tych ubiegłego wieku, rola ponadnarodowych organizacji rolniczych ulega systematycznemu zmniejszeniu, gdyż wspólna polityka rolna utraciła status najważniejszej polityki sektorowej.

Główną słabością organizacji rolniczych jest to, że z trudem dostosowują się do nowych wyzwań stojących przez unijnym rolnictwem, konsekwentnie od lat przeciwstawiając się koniecznym reformom wspólnej polityki rolnej, zmierzającym w kierunku obniżenia wydatków budżetowych i poziomu cen rolnych, ograniczenia nadprodukcji rolnej itd. ${ }^{28}$ Takie stanowisko zajęły COPA-COGECA w sprawie projektu reform rolnych w ramach Agendy 2000. Krytyczne stanowisko zajęły także w stosunku do komunikatu Komisji do Parlamentu Europejskiego, Rady, Parlamentu Europejskiego, Komitetu Ekonomiczno-Społecznego i Komitetu Regionów odnośnie do przyszłości wspólnej polityki rolnej do 2020 r. pt: „Sprostać wyzwaniom przyszłości związanym z żywnością, zasobami naturalnymi oraz aspektami terytorialnymi" 29 . Ponadnarodowe organizacje rolnicze domagały się także usztywnienia stanowiska organów unijnych podczas negocjacji w ramach WTO. Nastawienie lobby rolniczego na blokowanie reform na poziomie unijnym zdaje się prowadzić do mało optymistycznego wniosku, że celem ich działania nie jest modernizacja sektora rolnego w obliczu nowych wyzwań, lecz subsydiowanie możliwie jak największej liczby rolników.

Zauważyć przy tym należy, że organizacje rolnicze reagują pozytywnie na te reformy wspólnej polityki rolnej, które korespondują z ich partykularnymi interesami. I tak COPA-COGECA poparły porozumienie w sprawie pakietu klimatycznego zawarte na 15 konferencji ONZ w Kopenhadze w grudniu 2009 r. Ponadto COPA wsparła polskie stanowisko w sprawie wprowadzenia w 2006 r. na okres pięcioletni ceł antydumpingowych na mrożone truskawki z Chin. W dążeniu do realizacji pragmatycznych interesów organizacje rolnicze posługują się często ideologicznymi hasłami, tak jak np. miało to miejsce w czasie wielkich manifestacji rolniczych w 1999 r., w których rolnicy uczestniczyli pod hasłami „,Sprawiedliwość dla rolników”, „Nie pozwólmy zniszczyć naszych rodzin”"30.

Zauważyć przy tym należy, że o ile do początku lat 90-tych organizacje te działały na zasadzie monopolu w ten sposób, że były jedynymi partnerami Komisji reprezentującymi interesy zawodowe rolników ${ }^{31}$, tak obecnie obok nich pojawili się nowi partnerzy społeczni, reprezentujący przeciwstawne wobec lobby rolniczego interesy. Dynamiczna działalność organizacji ekologicznych oraz ochrony praw konsumentów organizujących wiele kampanii lobbingowych w znacznym stopniu przyczynia się do systematycznego osłabiania wpływów organizacji rolniczych. Jak

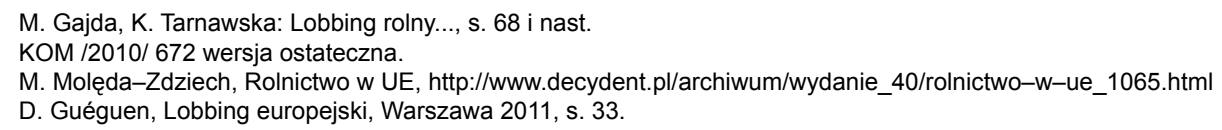


podaje się w literaturze, przyczyną mniejszej skuteczności organizacji rolniczych jest także heterogeniczność europejskiego rolnictwa, związana z kolejnymi rozszerzeniami UE o nowe państwa członkowskie i rosnącą liczbą organizacji krajowych zrzeszonych w ramach struktur ponadnarodowych ${ }^{32}$. Wobec zasadniczych różnic między tymi organizacjami z coraz większym trudem na poziomie unijnym wypracowywane są wspólne stanowiska zmierzające do skutecznego rozwiązywania narastających problemów sektora rolnego UE wynikających z nowych wyzwań. 


\section{Legitimization of the organizations of farmers in the EU and their influence on regulations of EU agricultural law}

Key words: supranational agricultural professional organization, social dialog, common agricultural policy

Taking under consideration the increasing importance of social dialog which should contribute to intensify the democratization of decision-making process in EU, the main aim of this article is to present the influence of supranational agricultural professional organizations on the shape of common agricultural policy and agricultural legislation which regulates it. Such organizations were established in the latter half of fifties of the past century to protect and represent interests of different categories of farmers from particular member states (e.g. interests of young farmers, cooperatives or workers in agriculture) on European forum. Among such organizations COPA Committee of Agricultural Professional Organizations (Comité des Organisations Professionelles Agricoles de l'Union Europénne) is deemed to be the most influential lobbing organization. Within this article there were presented legal conditions which should be fulfilled by supranational agricultural organizations to participate in the mechanisms of social dialog on the EU forum. There were also discussed functions of supranational agricultural professional organizations with special stress on their contribution in the process of making EU law, mainly in the advisory forms. On the background of analysis made in this article, there is picked up an attempt to evaluate the effectiveness of actions taken by the supranational agricultural organizations in the sphere of agricultural sector. 